\title{
Program pomysłów pracowniczych jako narzędzie innowacyjności oddolnej w małych przedsiębiorstwach przemysłowych
}

\author{
RAFAe MARCIN BORKOWSKI \\ Wydział Zarzadzania Szkoły Wyższej im. Pawła Włodkowica w Płocku
}

\begin{abstract}
Motorem napędowym innowacyjności w małych przedsiębiorstwach jest przede wszystkim środowisko pracy. Małe firmy charakteryzuje brak skostniałej struktury organizacyjnej, elastyczne reagowanie na zmiany rynku, czy możliwość udziału pracowników w bezpośrednim kreowaniu nowych produktów bądź usług. Ze względu na niski poziom innowacyjności małych przedsiębiorstw, wynikający często z ograniczeń kapitału rzeczowego i finansowego, małe podmioty gospodarcze powinny częściej korzystać z narzędzi umożliwiających wykorzystanie potencjału swoich pracowników. Celem artykułu jest wskazanie zasadności stymulowania pracowników małych przedsiębiorstw do wykorzystywania umiejętności twórczego myślenia, kreatywności i zaangażowania w podejmowaniu innowacyjnych działań w firmie. Jednym $\mathrm{z}$ instrumentów innowacyjności oddolnej stosowanym w małych przedsiębiorstwach jest program pomysłów pracowniczych.
\end{abstract}

Słowa kluczowe: innowacyjność, kreatywność, twórcze myślenie, pomysły pracownicze, małe przedsiębiorstwa.

\section{Wstęp}

We współczesnej gospodarce krajowej, będącej w okresie niestabilności rynku, coraz bardziej dostrzega się znaczenie małych przedsiębiorstw w elastycznej adaptacji do istniejącej rzeczywistości. Małe podmioty gospodarcze od czasów kryzysu gospodarczego w Polsce w 2007 roku udowodniły, że są cennym graczem na rynku i strategicznym partnerem biznesowym średnich i dużych przedsiębiorstw. Ich elastyczność i szybkość dopasowania się do zmian jest dla partnerów 
gwarantem realizacji usług oraz produkcji dóbr zgodnych z oczekiwaniami coraz bardziej wymagających klientów. Małe podmioty gospodarcze postrzegane są współcześnie jako motor zmian i środowisko generowania innowacji. Ze względu na ich niską innowacyjność poszukuje się narzędzi umożliwiających tworzenie usprawnień miejsca pracy, procesów produkcyjnych oraz generowania koncepcji umożliwiających wprowadzanie na rynek nowych produktów.

\section{Innowacyjność małych przedsiębiorstw}

W literaturze przedmiotu nie ma jednoznacznej definicji małego przedsiębiorstwa. Zróżnicowane uwarunkowania społeczno-gospodarcze państw oraz branże, w których funkcjonują podmioty gospodarcze, uniemożliwiają sformułowanie obligatoryjnej definicji małego przedsiębiorstwa. Teoria i praktyka dotycząca zarządzania przedsiębiorstwami sektora MSP wskazuje na dwa główne kryteria w definiowaniu małych i średnich firm:

- jakościowe - bazują w większości przypadków na systemie zarządzania, poziomie innowacyjności, charakterystyce struktury organizacyjnej, decyzyjności oraz integralności własności,

- ilościowe - dotyczą przede wszystkim mierzalnych aspektów przedsiębiorstwa, a więc liczby zatrudnionych pracowników, wielkości obrotu, wielkości aktywów, zasięgu rynku zbytu, roczne obroty, suma roczna bilansu (Janiuk, 2004). Zgodnie z europejskimi kryteriami dla sektora $\mathrm{MSP}^{1}$ zostały wyodrębnione mikro, małe i średnie przedsiębiorstwa. Za małe przedsiębiorstwo uznaje się to, którego średnioroczne zatrudnienie w przeliczeniu na pełne etaty to 10-49 pracowników, obrót roczny netto nie przekracza 10 mln euro lub suma aktywów bilansu nie przekracza $10 \mathrm{mln}$ euro oraz niezależność kapitałowa od innych podmiotów jest poniżej 25\% kapitału lub głosów w innych przedsiębiorstwach (Matejun, 2012).

Współczesne małe przedsiębiorstwa działają na rynku tradycyjnym, w niszach rynkowych w obszarze zaawansowanych technologii (high-tech), a także często są

1 Najczęściej przyjmuje się definiowanie małych przedsiębiorstw w oparciu o kryteria ilościowe mierzalne. Należy jednak zaznaczyć, że „postrzeganie małych firm wyłącznie w kategoriach ilościowych może prowadzić do błędnych wniosków co do sposobów ich funkcjonowania i budowania przewagi strategicznej na rynku. Najmniejsze organizacje nie są miniaturową wersją dużych przedsiębiorstw, a o ich specyfice decyduje wiele cech o charakterze jakościowym" (Glinka, Gudkova, 2011, s. 29). Będąc członkiem Unii Europejskiej przyjęliśmy z dniem 1 stycznia 2005 roku formalną definicję małych i średnich przedsiębiorstw wynikającą z wcześniejszych zaleceń i ostatecznie rozporządzenia Komisji Europejskiej, która następnie znalazła się w ustawie o swobodzie działalności gospodarczej. 
przedsiębiorstwami wirtualnymi. Ich zróżnicowanie rodzajowe i branżowe ukazuje umiejętność wykorzystywania szans rynkowych oraz adaptacji sposobu wytwarzania produktu bądź świadczenia usług do zmieniających się wymagań klientów. Szybkość dostosowania się do zmieniających się wymogów otoczenia, spłaszczona struktura organizacyjna oraz kultura organizacyjna zorientowana na klienta umożliwia małym przedsiębiorstwom generowanie, stosowanie i absorpcję innowacji. Małe podmioty gospodarcze, które podejmują ryzyko generowania innowacyjnych produktów/usług zdają sobie sprawę z tego, że jest to szansa zwrócenia na siebie uwagi na rynku krajowym oraz impuls do gry na rynku międzynarodowym. Dysponując ograniczonym kapitałem finansowym i rzeczowym, ale za to twórczym zespołem pracowników zorientowanym na ulepszanie, modyfikację oraz tworzenie nowych produktów/usług, małe przedsiębiorstwa mogą w krótszym okresie niż to można zauważyć w dużych przedsiębiorstwach dostosować swoje produkty/ usługi do nawet najbardziej wymagających klientów. „Innowatorzy i przedsiębiorcy z Doliny Krzemowej od dawna dobrze znają prawdę, że nie wygrywa ten pomysł, który jest najlepszy, lecz ten, który najszybciej zostanie zrealizowany"(Deschamps, 2011). Dynamizm działania małych przedsiębiorstw w produkcji i realizacji usług na niewielką skalę w globalnej gospodarce zmusza je do poszukiwania ulepszeń organizacyjnych i technicznych, których efektem końcowym są wprowadzone na rynek ulepszone bądź nowe produkty/usługi. Potwierdzeniem tych działań jest niewątpliwie teoria twórczej destrukcji J. Schumpetera charakteryzująca się niszczeniem starych struktur, systemów na rzecz nowych i wprowadzająca do światowej literatury ekonomicznej pojęcie innowacji rozumianej jako:

- wprowadzenie na rynek nowego bądź udoskonalonego produktu,

- wprowadzenie nowej lub udoskonalonej metody produkcji,

- otwarcie pionierskiego rynku,

- wprowadzenie na rynek nowych surowców bądź półfabrykatów,

- przeprowadzenie nowej organizacji produkcji (Schumpeter, 1995).

Schumpeterowskie ujęcie innowacji sprowadza się przede wszystkim do działalności przedsiębiorstw przemysłowych będących podstawą gospodarki kapitalistycznej XX wieku. Współczesne ujęcie innowacji dotyczy szerokiego i wąskiego rozumienia tego pojęcia. Innowacje sensu largo traktowane są przede wszystkim jako zmiany mające miejsce w gospodarce, technice, jak i systemie społecznym (Stawasz, 1999). Dla J.A. Allena jest ona ideą, praktyką lub obiektem postrzeganym jako nowość przez osobę lub inną jednostkę przyjmującą (Allen, 1966). Natomiast innowacja sensu stricto to „pierwsze handlowe wprowadzenie nowego produktu, procesu, systemu lub urządzenia" (Freeman, 1982) i precyzujące ową definicję sformułowanie E. Mansfielda, że „innowację stanowi pierwsze zastosowanie wynalazku" (Mansfield, 1968). Współcześnie dostrzega się pewną modę na 
innowacje, każda zmiana mała (usprawniająca), czy duża (radykalna, strategiczna) nazywana jest innowacją. Stała się ona także marketingową dźwignią reklamy zorientowaną na pozyskanie jak największej liczby klientów. Powoduje to „stłamszenie" znaczenia innowacji prezentowanej w światowej literaturze ekonomicznej i biznesowej.

Małe przedsiębiorstwa utożsamiane są zazwyczaj z generowaniem innowacji wymuszonych, realizowanych w sytuacjach problemowych dla firmy, zmierzających najczęściej do obniżenia kosztów. Nie jest to prawda, ponieważ małe podmioty gospodarcze wprowadzają także innowacje rutynowe, usprawniające wyrób/usługę w celu ukazania ich atrakcyjności oraz innowacje wynikające z okazji rynkowych, umożliwiające wprowadzenie do oferty nowego produktu bądź usługi zgodnej z zapotrzebowaniami klientów (Webber, 1996). Innowacyjność małych przedsiębiorstw to przede wszystkim umiejętność wykorzystywania okazji rynkowych związana z generowaniem zmian mających oddźwięk społeczno-gospodarczy. Innowacyjność jest połączeniem inwencji i implementacji. Inwencja to umiejętność odpowiadania na potrzeby rynku, dostrzegania szans i tworzenia produktów/usług zgodnych $\mathrm{z}$ oczekiwaniami odbiorców. Implementacja to natomiast moment testowania nowej usługi bądź produktu i po zebraniu większości pozytywnych opinii wprowadzenia danego dobra na rynek.

Innowacyjność przedsiębiorstw może być postrzegana w dwóch trybach: oddolnym oraz odgórnym. Innowacyjność oddolna to przede wszystkim innowacyjne idee, których autorami są pracownicy różnych szczebli. Każdy z pracowników ma możliwość opracowania innowacyjnego projektu zgodnego z celami biznesowymi przedsiębiorstwa, które następnie oceniane są pod kątem możliwości finansowych i rzeczowych przedsiębiorstwa oraz korzyści płynących z wdrożenia i zastosowania tego projektu (Deschamps, 2011). W firmach przemysłowych są to najczęściej idee dotyczące innowacji procesowych i produktowych natomiast w małych firmach usługowych to innowacje marketingowe i organizacyjne. Motorem napędowym innowacyjności oddolnej jest przede wszystkim środowisko pracy małych przedsiębiorstw charakteryzujące się elastycznością kompetencyjną pracowników, krótkim procesem komunikacji, dzieleniem się wiedzą, bezpośrednim kontaktem z właścicielem i menedżerami przedsiębiorstwa, szybkim procesem podejmowania decyzji i reagowania na zmiany gospodarki, podejmowaniem ryzyka oraz możliwością udziału pracowników w bezpośrednim kreowaniu nowych produktów/usług zgodnych z zapotrzebowaniami rynku. Innowacyjność odgórna natomiast jest przede wszystkim inicjowana przez właściciela/menedżera małego przedsiębiorstwa, która następnie realizowana jest przez zespół operacyjny.

Współczesne przedsiębiorstwa zarówno sektora MSP, jak i duże podmioty gospodarcze zwracają się raczej w kierunku innowacyjności oddolnej, w każdym 
przedsiębiorstwie są talenty, które czekają na możliwość generowania innowacyjnych projektów. Właściciele/menedżerowie małych przedsiębiorstw starają się korzystać z elastyczności swoich pracowników, którzy potrafią wykonywać obowiązki przypisane różnym stanowiskom pracy, przez co posiadają uniwersalną wiedzę, umiejętności i chęć do podejmowania wyzwań zawodowych umożliwiających generowanie nowych pomysłów i pobudzanie kreatywności.

\section{Program pomysłów pracowniczych generatorem zachowań innowacyjnych w pracy}

Pracownicy małych przedsiębiorstw przemysłowych to jednostki wyposażone w uniwersalną wiedzę, motywację wewnętrzną do pracy, chęć uczenia się i dzielenia się nabytą wiedzą z innymi członkami tej organizacji. Małe przedsiębiorstwa w przeciwieństwie do dużych podmiotów gospodarczych nie posiadają skostniałej struktury organizacyjnej i „rygoru” podporządkowania się pomysłom menedżerów. W małym przedsiębiorstwie właściciel, menedżerowie i pracownicy pionu operacyjnego to przede wszystkim dobrze zorganizowany zespół, który dynamicznie działa na rzecz rozwoju przedsiębiorstwa, zapewniając sobie miejsce pracy oraz możliwość realizowania nowatorskich pomysłów, których efektem są usprawnienia techniczne czy organizacyjne oraz nowe produkty zgodne z zapotrzebowaniami coraz bardziej wymagających klientów. Kompetencje pracowników małych przedsiębiorstw są współcześnie ich motorem napędowym, warunkującym tworzenie, stosowanie i absorpcję innowacji. Małym przedsiębiorstwom łatwiej jest stworzyć mechanizm, „który umożliwi systematyczne zbieranie owoców indywidualnej wynalazczości pracowników, niejako prosto z głów" (Deschamps, 2011).

Zgodnie z myślą T.W. Schultz'a to czynnik ludzki jest jednym $z$ istotnych czynników w generowaniu innowacji w przedsiębiorstwie (Schultz, 1976). „To pracownik ze swoją wiedzą, kwalifikacjami i świadomością dotyczącą roli działań innowacyjnych jest najbardziej przyszłościowym wskaźnikiem rozwoju przedsiębiorstwa. Od jego stosunku do innowacji, odpowiedniego poziomu motywacji, kreatywności i zaangażowania zależy poziom osiąganej przez firmę aktywności innowacyjnej" (Strzelecka, 2011). Według M. Juchnowicz „potencjał kompetencyjny pracowników oraz wiedza organizacyjna stały się głównym sposobem uzyskiwania i utrzymywania przewagi konkurencyjnej. Zdecydowała o tym szczególna elastyczność zasobu ludzkiego, to znaczy możliwość szybkiego dostosowywania się do zmian w strategii działania firmy" (Juchnowicz, 2007). Warto zauważyć, że współczesne kompetencje pracowników należy rozumieć jako dysponowanie wiedzą, umiejętnościami, postawami oraz zachowaniami warunkującymi realizację celów 
biznesowych przedsiębiorstwa. Potencjał kompetencyjny pracowników małych przedsiębiorstw postrzegany jest przez ich elastyczność w reagowaniu na zmiany otoczenia i szybkie dostosowanie do nich, a także elastyczność zadaniową rozumianą jako umiejętność podejmowania działań na różnych stanowiskach pracy.

Coraz częściej zwraca się uwagę na zachowania pracowników, prowadzące do generowania innowacji. Zachowania produktywne pracowników zorientowane są przede wszystkim na zaspokojenie potrzeb klientów. Umiejętność twórczego myślenia, kreatywność warunkuje tworzenie oryginalnych pomysłów, będących zalążkiem innowacji i podstawą sukcesu rynkowego małego przedsiębiorstwa. Zachowania kreacyjne pracowników odnoszą się do "generowania nowych rozwiązań przy odwoływaniu się do heurystyk, które mają charakter ogólny i nie precyzują wskazówek dotyczących kierunku działań koniecznych do rozwiązania problemu; (...) dzięki zachowaniom regulacyjnym pracownik mobilizuje zasoby poznawcze do wykonania zadania (...), do jego trudności i kontynuowania wysiłku na rzecz jego zakończenia" (Wojtczuk-Turek, 2012). Według F. Yuan i R.W. Woodman zachowania innowacyjne w pracy to przede wszystkim aktywność pracowników zorientowana na generowanie nowych pomysłów zarówno własnych jak i zapożyczonych (imitacja), których efektem końcowym jest ich wdrożenie i realizacja w celu osiągnięcia wartości dodanej przedsiębiorstwa (Yuan, Woodman, 2010). Pomysł pracownika na udoskonalenie produktu, procesu produkcyjnego, organizacyjnego, marketingowego bądź stworzenie nowatorskiego produktu jest zalążkiem procesu innowacyjnego przedsiębiorstwa. Źródłem pomysłu jest kreatywność rozumiana jako proces „rozwijania i wdrażania nowatorskich pomysłów w celu rozwiązania problemów lub zaspokojenia potrzeb własnych i organizacji, (...) jest celowym procesem wytwarzania innowacji (...), składającym się z trzech komponentów: wiedzy, umiejętności twórczego myślenia i motywacji" (Harvard Business Essentials, 2005). Według A. Pocztowskiego kreatywność można postrzegać jako zróżnicowaną międzyosobniczo cechę człowieka warunkującą wytwarzanie nowych pomysłów wykorzystującą wiedzę, doświadczenie i olśnienie twórcze wynikające z wykorzystania wyobraźni, których efektem końcowym jest opracowana koncepcja, sposób wytwarzania produktu, bądź system zmian organizacyjnych usprawniających proces technologiczny w przedsiębiorstwach przemysłowych (Pocztowski, 2008). Zgodnie z teorią organizacyjnej kreatywności T.M. Amabile wiedza techniczna i specjalistyczna cechująca się znajomością procedur, motywacja wewnętrzna oraz umiejętność twórczego myślenia - elastyczność w wykorzystywaniu własnej wyobraźni dla realizacji celów biznesowych przedsiębiorstwa przyczyniają się do pobudzania kreatywności w miejscu pracy (Amabile, 1998). Należy jednak zwrócić uwagę na fakt, że sama kreatywność nie zakłada realizacji innowacyjnego produktu, stanowi tylko „istotny element zachowań innowacyjnych, najbardziej 
widoczny na początku procesu innowacyjnego" (Turek, 2012). Zatem kreatywność jest tylko impulsem $\mathrm{w}$ inicjowaniu nowych idei w powiązaniu $\mathrm{z}$ istniejącymi w przedsiębiorstwie procesami produkcji i systemem zarządzania. Dopiero w połączeniu z umiejętnością twórczego myślenia będącą wiązką elastycznego podejścia do rozwiązania problemów i nowego spojrzenia na warunki panujące w dynamicznie zmieniającej się rzeczywistości, dochodzi do poszukiwania różnych kierunków zastosowania pomysłu. „Twórcze myślenie w przedsiębiorczym działaniu staje się potrzebne, aby można było wcześnie przygotować się do możliwych zmian w otoczeniu, wykrywać szanse i zagrożenia, systematycznie badać obszary wysokiej szansy, aby na tej podstawie kreować nowatorskie rozwiązania i radzić sobie z coraz trudniejszą przyszłością" (Heninborch-Buhaj, 2012).

Nie zawsze każdy pomysł pracownika jest zgodny z realiami rynku i możliwościami finansowymi przedsiębiorstwa. Weryfikacji istotności pomysłów w małych przedsiębiorstwach przemysłowych służy narzędzie, jakim jest program pomysłów pracowniczych ${ }^{2}$. Zakłada on rozpowszechnienie wartościowych rozwiązań metod pracy oraz nowatorskich działań mających bezpośredni wpływ na poprawę warunków pracy, procesów produkcyjnych, organizacyjnych i generowania koncepcji wytworzenia nowych produktów zorientowanych na wymagania rynku, co w efekcie przekłada się na wyniki biznesowe firmy. Poniższy opis programu pomysłów pracowniczych został przedstawiony w oparciu o informacje uzyskane z indywidualnych wywiadów pogłębionych z właścicielami małych przedsiębiorstw innowacyjnych podregionu ciechanowsko-płockiego, w których ten instrument innowacyjności oddolnej miał zastosowanie. Program pomysłów pracowniczych w badanych małych przedsiębiorstwach to instrument skierowany do pracowników operacyjnych (nie zajmujących stanowisk kierowniczych) w przedsiębiorstwie. Jego celem jest pobudzanie kreatywności i umiejętności twórczego myślenia oraz zaangażowania pracowników w poszukiwanie miejsc do projektowania usprawnień i ich wdrażania oraz opracowywania koncepcji tworzenia nowych produktów wynikających z potrzeb klientów. Regulamin programu pomysłów pracowniczych $\mathrm{w}$ innowacyjnych małych przedsiębiorstwach przemysłowych stanowi podstawę jego funkcjonowania, określa warunki uczestnictwa pracowników w programie, jego realizację oraz zasady wyłaniania i nagradzania nowatorskich pomysłów.

2 Opis narzędzia jakim jest program pomysłów pracowniczych pochodzi z analizy pilotażu badań jakościowych przeprowadzonych w innowacyjnych małych przedsiębiorstwach przemysłowych podregionu ciechanowsko-płockiego, w skład którego wchodzą: powiat ciechanowski, mławski, płocki, miasto Płock, sierpecki, gostyniński, żuromiński i płoński. Przeprowadzono 10 indywidualnych wywiadów pogłębionych (częściowo ustrukturyzowane) z właścicielami innowacyjnych małych przedsiębiorstw, które w przeciągu ostatnich 3 lat wprowadziły co najmniej jedną innowację. Wywiady zostały przeprowadzone w lutym 2013 roku. 
Do programu pomysłów pracowniczych mogą być zgłaszane zarówno projekty usprawnień miejsc pracy, jak i problemy wymagające rozwiązań w zakresie udoskonalenia istniejących procesów i koncepcji generowania nowych produktów. Powołana Komisja Oceniająca, w skład której wchodzą: właściciel, menedżerowie, liderzy procesu produkcji, analizuje skuteczność wdrożeniową zgłaszanych pomysłów przy wykorzystaniu posiadanych zasobów oraz ich zgodność z wymaganiami rynku. Zgłoszenie pomysłu może być indywidualne lub zespołowe. Projekty zgłaszane są na specjalnie opracowanym w tym celu formularzu dostępnym u przełożonego, zawierającym następujące informacje:

- imię, nazwisko pracownika (grupy pracowników) zgłaszającego projekt wraz $\mathrm{z}$ jego numerem ewidencyjnym,

- datę zgłoszenia pomysłu,

- nazwę projektu,

- opis projektu (w uzasadnionych przypadkach z jego szkicem),

- kosztorys projektu (przewidywany czas na realizację projektu oraz całkowity koszt jego wdrożenia),

- listę osób w tym konsultantów wewnętrznych i zewnętrznych niezbędnych do realizacji projektu,

- miejsce na ocenę projektu pod względem każdego z obszarów oceny,

- podpis pracownika/pracowników zgłaszających projekt.

Formularz składany jest u właściciela - będącego Przewodniczącym Komisji Oceniającej Programu Pomysłów Pracowniczych. Głównymi kryteriami oceny zgłaszanych projektów są:

- innowacyjność,

- jakość i termin realizacji,

- poprawa metod pracy i procesu produkcyjnego,

- realne koszty i możliwości wdrożenia,

- wpływ na realizację celów biznesowych przedsiębiorstwa,

- zorientowanie na potrzeby klientów.

$\mathrm{Z}$ uwagi na zmieniające się uwarunkowania rynkowe oraz priorytety przedsiębiorstwa, raz na kwartał dokonywana jest weryfikacja kryteriów oceny. Pracownik (grupa pracowników) zgłaszający projekt bierze udział w spotkaniu oceniającym, podczas którego może zostać poproszony o udzielenie odpowiedzi na pytania, dotyczące istoty opisanego we wniosku pomysłu i następstw jego wdrożenia oraz zastosowanie w przedsiębiorstwie. W terminie 7 dni od spotkania oceniającego, pracownik (grupa pracowników) zgłaszający projekt otrzymuje informację zwrotną w formie pisemnej na temat oceny jakościowej projektu w oparciu o przyjęte kryteria z informacją o przyjęciu pomysłu do realizacji bądź jego odrzuceniu. Wdrożenie pomysłu jest równoznaczne z przyznaniem pracownikowi lub grupie pracowników 
nagrody finansowej w wysokości zależnej od typu projektu: usprawnienie metody pracy, procesu produkcyjnego, opracowanie koncepcji wdrożenia i zastosowania nowego produktu zorientowanego na potrzeby rynku. Pracownik lub grupa pracowników, których pomysł został odrzucony przez Komisję Oceniającą otrzymują punkty za motywację i zaangażowanie do usprawnienia procesów przedsiębiorstwa. Punkty wymieniane są na nagrody rzeczowe ujęte w katalogu nagród. Liczba otrzymanych punktów uzależniona jest od liczby spełnionych kryteriów. Punkty są rozdzielane równo pomiędzy uczestników zespołu zgłaszającego projekt bez względu na to, jaki wkład pracy włożyli w przygotowanie i zgłoszenie przedsięwzięcia. Pracownik lub grupa pracowników, zgłaszający pomysł, sami decydują o terminie wymiany punktów na nagrody. Program pomysłów pracowniczych zapewnia innowacyjnym, małym przedsiębiorstwom przemysłowym możliwość wykorzystania jawnego i uśpionego potencjału, tkwiącego w pracownikach operacyjnych, w tworzeniu usprawnień oraz realizacji koncepcji wprowadzenia nowego produktu na rynek.

\section{Podsumowanie}

Program pomysłów pracowniczych w małych przedsiębiorstwach przemysłowych jest niewątpliwie narzędziem, które pomaga wykorzystać potencjał kompetencyjny pracowników $\mathrm{w}$ realizacji usprawnień produkcyjnych i organizacyjnych oraz warunkuje generowanie nowych produktów zgodnych z oczekiwaniami coraz to bardziej wymagających klientów. Skrócenie cyklu życia produktów zmusza firmy do innowacyjności w celu wyróżnienia się na dynamicznie zmieniającym się rynku. Małe przedsiębiorstwa ze względu na swoją elastyczność w adaptacji do zmian gospodarki są podmiotami, które najszybciej mogą usprawniać i wprowadzać na rynek nowe produkty zgodnie z istniejącym zapotrzebowaniem. Coraz bardziej wymagający klient oczekuje produktu, który będzie funkcjonalny, dobrej jakości, ale także poprzez design będzie odróżniał się od innych podobnych produktów Stymulowanie pracowników małych przedsiębiorstw przemysłowych do wykorzystania umiejętności twórczego myślenia, kreatywności i zaangażowania przy pomocy programu pomysłów pracowniczych umożliwia tworzenie innowacji w firmie zgodnych z potrzebami klientów, co także ma wpływ na zwiększenie jej pozycji na rynku. 


\section{Bibliografia}

Allen, J.A. (1966), Scientific innovation and industrial prosperity, Longman, London.

Amabile, T.M. (1998), How to Kill Creativity, „Harvard Business Review”, wrzesień-październik.

Deschamps, J.P. (2011), Liderzy innowacyjności. Jak rozwijać i utrzymywać innowacyjność $w$ firmie, Oficyna Wolters Kluwer Business, Warszawa.

Freeman, Ch. (1982), The economic of industrial innovation, Printer, London.

Glinka, B., Gudkova, S. (2011), Przedsiębiorczość, Oficyna Wolters Kluwer Business, Warszawa.

Harvard Business Essentials (2005), Zarzq̨dzanie kreatywnościq i innowacją, MT Biznes, Konstancin-Jeziorna.

Heninborch-Buhaj, M. (2012), Stymulowanie kreatywności jako wyzwanie ery konceptualnej wobec zarządzania przedsiębiorczością pracowników, w: B. Jamka (red.), Potencjat ludzki w rozwoju przedsiębiorczości indywidualnej i korporacyjnej, Difin, Warszawa.

Janiuk, I. (2004), Strategiczne dostosowanie małych i średnich przedsiębiorstw do konkurencji europejskiej, Difin, Warszawa.

Juchnowicz, M. (2007), Kapitał ludzki w organizacji wiedzy, w: M. Juchnowicz (red.), Elastyczne zarządzanie kapitałem ludzkim w organizacji wiedzy, Difin, Warszawa.

Mansfield E. (1968), Industrial research and technological innovation, Norton, New York.

Matejuk, M. (2012) (red.), Zarzqdzanie mała i średniq firmą. W teorii i ćwiczeniach, Difin, Warszawa.

Pocztowski, A. (2008) (red.), Zarzadzanie talentami $w$ organizacji, Oficyna Wolters Kluwer, Kraków 2008.

Schulz, T.W. (1976), Investment in Human Capital, The Free Press, New York.

Schumpeter, J.A. (1995), Socjalizm, Kapitalizm, Demokracja, Wydawnictwo Naukowe PWN, Warszawa.

Stawasz, E. (1999), Innowacje a mała firma, Wydawnictwo Uniwersytetu Łódzkiego, Łódź.

Strzelecka, R. (2011), Innowacyjność jako czynnik rozwoju małych i średnich przedsiębiorstw $w$ okresie spowolnienia gospodarczego, w: A. Zakrzewska-Bielawska (red.), Wyzwania rozwojowe matych $i$ średnich przedsiębiorstw. Innowacje. Technologie. Kryzys, Difin, Warszawa.

Turek, D. (2012), Przedsiębiorca a pracownik przedsiębiorczy. Podobieństwa i różnice profili kompetencyjnych i ich implikacje dla procesów zarzq̨dzania, w: B. Jamka (red.), Potencjał ludzki w rozwoju przedsiębiorczości indywidualnej i korporacyjnej, Difin, Warszawa.

Webber, R.A. (1996), Zasady zarzadzania organizacjami, PWE, Warszawa.

Wojtczuk-Turek, A. (2012), Zachowania innowacyjne w pracy. Wybrane zagadnienia teoretyczne i praktyczne, Difin, Warszawa. 
Yuan, F., Woodman, R.W. (2010), Innovative Behavior in the Workplace. The Role of Performance and Image Outcome Expectations, "Academy of Management Journal", vol. 53/2.

\section{Summary}

\section{Employee Ideas Program as Tool for Grassroots Innovation of Small Industrial Enterprises}

The driving force of innovation in small enterprises is primarily the working environment. Small business is characterized by the lack of ossified organizational structure, flexible response to changes in the market, or the possibility of participation of employees in the direct creation of new products or services. Due to the low level of innovation in small businesses, often resulting from the constraints of physical and financial capital, small business managers should frequently use available tools to realize the potential of their employees. The purpose of this article is to identify the merits of stimulating employees of small companies to use creative thinking skills, creativity and commitment to making innovative activities in the company. One of the instruments using grassroots innovation in small enterprises is a program of employee ideas.

Keywords: innovation, creativity, creative thinking, ideas, labor, small businesses.

\section{Резюме}

\section{Программа идей сотруАников как инструмент инновационности снизу на махых преАприятиях}

Движущей силой инновационности на малых предприятиях является прежде всего трудовая среда. Малые фирмы характеризуют отсутствие окостеневшей организационной структуры, гибкое реагирование на изменения рынка и возможность участия сотрудников в непосредственном создании новых продуктов или услуг. Учитывая низкий уровень инновационности малых предприятий, являющийся часто следствием ограничений материально-вещественного и финансового капитала, малые экономические субъекты должны чаще пользоваться 
инструментами, предоставляющими возможность использования потенциала своих работников. Цель настоящей статьи - подчеркнуть обоснованность побуждения сотрудников малых предприятий к использованию умения творчески мыслить, креативности и к активному участию в инновационной деятельности фирмы. Одним из инструментов инновационности снизу на малых предприятиях является программа идей сотрудников.

Ключевые слова: инновационность, креативность, творческое мышление, идеи сотрудников, малые предприятия.

\section{Rafał Marcin Borkowski}

Doktorant Szkoły Głównej Handlowej w Warszawie w Zakładzie Strategii Konkurencji Instytutu Rynków i Konkurencji w Kolegium Nauk o Przedsiębiorstwie. Asystent Wydziału Zarządzania Szkoły Wyższej im. Pawła Włodkowica w Płocku oraz specjalista ds. badawczo-rozwojowych i innowacji w Płockim Parku Przemysłowo-Technologicznym. Członek Zarządu Stowarzyszenia na rzecz Wspierania Rozwoju Kapitału Ludzkiego, członek Rady ds. Innowacyjności i Działań B+R przy Prezydencie Miasta Płocka oraz trener biznesu i konsultant Bigram S.A. - Personnel Consulting. W swojej pracy badawczej koncentruje się głównie na zagadnieniach związanych z zarządzaniem zasobami ludzkimi, innowacyjnością przedsiębiorstw, zarządzaniem przedsiębiorstwami sektora MSP oraz współpracy nauki z biznesem. Autor kilkunastu opublikowanych artykułów naukowych oraz prelegent na wielu konferencjach naukowych i biznesowych. 